\section{Human Auto-Antiidiotypes Regulating T Cell-mediated Reactivity to Tetanus Toxoid}

Andrew Saxon and Eugene Barnett

Division of Clinical Immunology-Allergy and Rheumatology,

Department of Medicine, University of California, Los Angeles

School of Medicine, Los Angeles, California 90024 bstract. While investigating the effect on $B$ cells of repetitive in vivo immunization with tetanus toxoid (TT), we observed the subsequent development of specific anergy for $\mathrm{T}$ cell delayed hypersensitivity (DTH) to TT. This appeared $\sim 35 \mathrm{~d}$ after a series of five booster immunizations. Concurrently, in vitro $\mathrm{T}$ cell blastogenic responses were preserved. Serum obtained when the skin tests were nonreactive demonstrated a profound inhibitory activity on $\mathrm{T}$ cell reactivity. This activity was shown to be anti-antibody activity that was both anti-F(ab) ${ }_{2}^{\prime}$ and, specifically, anti-TT $F(a b)_{2}^{\prime}$. It blocked binding of TT to a pool of allogeneic antibodies and also inhibited allogeneic antigen-specific $T$ cell blastogenesis. Thus, we could identify activity in the serum of hyperimmunized individuals that appeared auto-anti-idiotypic (anti-id) and represented a single or family of major crossreacting idiotypes (id) for TT. The expression of the auto-anti-id correlated with the loss of $T$ cell reactivity in vivo and in vitro. Subsequent examinations revealed persistent, specific cutaneous anergy beyond six months, which was then associated with a failure of $T$ cells to react with antigen in vitro. Mixing experiments with cells from these later times and cryopreserved autologous cells obtained prior to hyperimmunization revealed there had been the development of antigen-specific $\mathrm{T}$ suppressor cells. Thus, in vivo DTH tolerance following hyperimmunization was associated with an inhibitory serum activity that appeared to be anti-id. Persistence of tolerance ( $>6 \mathrm{mo}$ ) occurred with the development of $T$ suppressor cells.

Dr. Saxon is the recipient of Allergic Diseases Academic Award AI00326. Address correspondence to Dr. Saxon.

Received for publication 7 December 1982 and in revised form 26 August 1983.

J. Clin. Invest.

(C) The American Society for Clinical Investigation, Inc.

0021-9738/84/02/0342/07 $\$ 1.00$

Volume 73, February 1984, 342-348

\section{Introduction}

The elements affecting expression of human immune responses have primarily focused upon antigen- or mitogen-mediated interactions (1). However, over the past decade, a rapidly expanding body of knowledge gained from animal experimentation has shown that idiotypic (id) 1 -anti-idiotypic (anti-id) interactions comprise an important set of interrelating events. This universe of id regulation is active in the control of the quantity and quality of humoral immune response because antigen-reactive B cells as well as $T$ helper cells bear surface id (2). Not surprisingly, similar id-anti-id reactions have occurred in the T-T cell interactions influencing expression of cell-mediated immunity $(3,4)$. Furthermore, the expression of id varies over time after immunization or repeated antigen challenge (5-7). While early studies relied on anti-id reagents raised by direct immunization with id, more recently the expression and role of auto-anti-id has gained increasing importance (8-10). Such auto-anti-id occur during both humoral and cell-mediated responses $(11,12)$.

The role of id-anti-id reactions or auto-anti-id antibodies in the expression of human immune reactions has just recently gained attention. Geha and Weinberg (13) have shown the existence of id-bearing cells and immunoglobulins using a rabbit heterosera. Furthermore, they demonstrated the effects of this material on $T$ and $B$ cell responses to tetanus toxoid (TT). Human auto-anti-id have been investigated primarily in systemic lupus erythematosis, where Abdou (14) first reported the presence of auto-anti-id to anti-DNA antibodies, an observation confirmed and extended by Nasu et al. (15).

While investigating the effect of repetitive immunization of the cells involved in the in vitro anti-tetanus toxoid antibody (anti-TT) response in humans, we observed that such individuals became anergic to delayed hypersensitivity (DTH) skin testing with TT. Investigation of this phenomenon suggests the early development of regulatory auto-anti-id antibodies followed by the later appearance of enhanced TT-specific T suppressor cells.

1. Abbreviations used in this paper: anti-TT, anti-tetanus toxoid antibody; DTH, delayed hypersensitivity; LF, flocculation units; id, idiotype; PBM, peripheral blood mononuclear cells; PWM, pokeweed mitogen; TT, tetanus toxoid. 
These studies provide further evidence for human auto-anti-id, documents their appearance in normals, and demonstrates a potential regulatory role in the expression of cell-mediated immunity.

\section{Methods}

Immunization and skin tests. Normal subjects between the ages of 25 and $49 \mathrm{yr}$ old were booster immunized on day 0 with 15 flocculation units (LF) (three times the usual booster dose) of soluble TT (Lederle Laboratories, Pearl River, NY) and subsequently with 5 U LF on days +14 and +28 . Serum and cells were obtained on day 0 and at various intervals thereafter. We performed skin testing on day -2 and at subsequent times as noted in the text. Subjects received a $0.1 \mathrm{ml}$ intradermal injection of $0.1 \mathrm{LF}$ soluble TT as described by Fairshter et al. (16). All skin tests were read at $48 \mathrm{~h}$. Induration and erythema were measured in their greatest diameter. We took a second measurement at right angles and then took an average of the two. All skin tests were performed on the volar aspect of the forearm; alternating arms were used for repetitive testing and sites on the same arm were always $6 \mathrm{~cm}$ apart. All donors had received previous TT immunizations but none in the last 12 mo. We performed other skin tests with streptokinase streptodornase 40:10 U (Lederle Laboratories) and Candida antigen 1:100 (Hollister Stier Laboratories, Spokane, WA).

Cell preparations. Peripheral blood mononuclear cells (PBM) were prepared by Ficoll-hypaque sedimentation (17). Viable cells were either tested fresh or cryopreserved. Lymphocyte blastogenesis was performed in round bottom 96-well microtitre plates (Falcon Labware, Oxnard, CA). 125,000 cells in RPMI 1640 with $15 \%$ fetal calf serum and $1 \%$ glutamine were seeded in wells either in the presence of TT $(5 \mu \mathrm{g})$, Candida antigen (1:250 final dilution of Hollister-Stier Laboratories, Candida 1:10), pokeweed mitogen (PWM) (1:100), or plain RPMI. The fetal calf serum (Hyclone lot 100361 Sterile Systems, Inc., Logan, UT) was chosen from lots screened for low background stimulation (500$1,000 \mathrm{cpm}$ range) at day 5 . Wells were pulsed with $2 \mu \mathrm{Ci}$ of tritiated thymidine on day 5 and harvested on a multi sample automated harvester $16 \mathrm{~h}$ later. Thymidine incorporation was assayed by liquid scintillation counting. Serum or putative anti-id reagents were added at time 0 as noted in the text. In some experiments, cryopreserved autologous cells from different time points were mixed $(100,000+100,000)$ and compared with one-half the counts derived from 200,000 of each cell type alone.

Preparation of auto-anti-id reagents. Serum from hyperimmunized donors (+day 36-48) was passed over an affinity column of $F(a b)_{2}^{\prime}$ of human immunoglobulin as previously described $(15,18)$. The bound material was eluted at low $\mathrm{pH}$, then passed over a column of TT bound by cyanogen bromide coupling to Sepharose 4B to remove any remaining anti-TT activity. In subsequent experiments, anti-TT were purified from serum obtained 10-14 d after booster immunization by affinity purification. The serum $(7.5 \mathrm{ml}$ diluted to 15 -in. $\mathrm{ml})$ was passed over 20 $\mathrm{ml}$ Sepharose 4B columns (2-4 mg TT/ml of Sepharose) which had been coupled with TT by the cyanogen bromide technique. The bound antibody was subsequently eluted at low $\mathrm{pH}$ and high ionic strength ( $25 \mathrm{ml}$ of $0.5 \mathrm{M} \mathrm{NaCl}$ and $0.5 \mathrm{M}$ acetic acid) and immediately neutralized. A $F(a b)_{2}^{\prime}$ fraction of this anti-TT was obtained by pepsin digestion followed by Sephadex G75 (Pharmacia Fine Chemicals Inc., Piscataway, NJ) separation (19). This material was cyanogen bromide coupled to Sepharose 4B columns as described above. Subsequently, sera from later time points from the same individuals (days 36-48) were passed over this $F(a b)_{2}^{\prime}$ anti-TT column and bound material eluted as described earlier. The anti-TT antibody in sera and other reagents was assayed by solid-phase radioimmunoassay (RIA) for IgG binding to TT (20). Anti-id activity was measured by inhibition of binding of IgG anti-TT antibodies from a standard pool of serum obtained from donors 10-14 d after booster immunization. This was compared with inhibition of binding of anti-diphtheria toxin antibodies in an analogous assay (20).

\section{Results}

Delayed hypersensitivity and serum levels to $T T$ in vivo. All donors had large DTH skin tests at day 0 . Thereafter, there was a progressive fall in skin reactivity so that the subjects were anergic to TT by day 42 (Fig. 1). This anergy was specific to TT as donors had reactive skin tests to streptokinase/streptodornase and Candida antigen. We followed this delayed skin test and subsequent anergy in 10 individuals; while the earliest return of any reactivity was seen at $5 \mathrm{mo}$, one individual remains anergic to TT 30 mo later (results not shown). Fig. 1 shows the effects of immunizations on anti-TT titres. Serum levels peaked between days 7 and 21 , then gradually declined thereafter. There was no rise in serum anti-TT antibody levels after boosters on day 14 or 28 , although serum levels did show a somewhat slower decline than we observed after a single booster. As with a single immunization, we observed no serum IgM anti-TT.

In vitro blastogenesis. PBM were assayed for blastogenic responses to soluble TT at days $0,14,28$, and 42 (Fig. 2). There was no significant change in specific blastogenesis to TT, Candida, or PWM. However, cells taken from two individuals at 6 and $7 \mathrm{mo}$ after showed diminished blastogenesis to TT; therefore, these cells were mixed 1:1 with autochthonous cryopreserved cells from days 0,14 , and 28 . These mixes lost far more reactivity

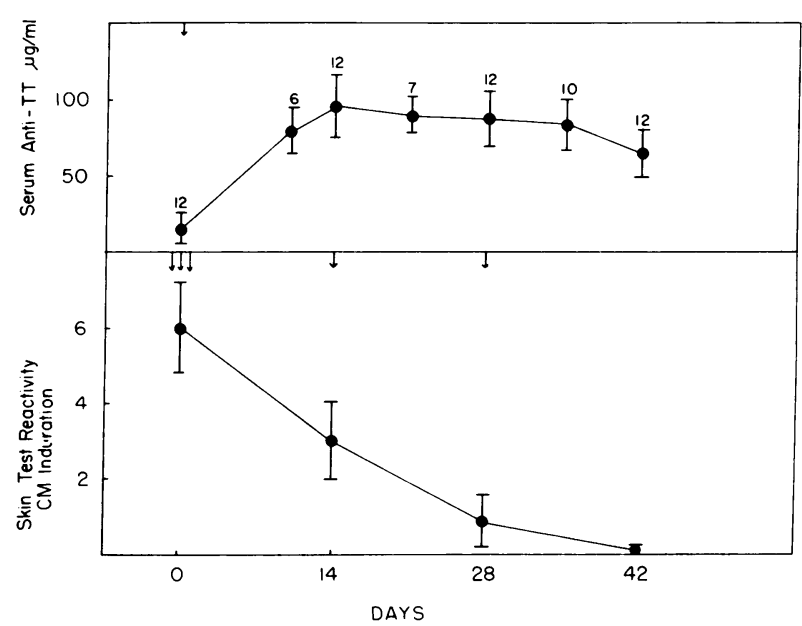

Figure 1. Delayed skin test reactivity to intradermal TT antibody response following repetitive immunization. Each arrow represents a booster immunization with 5 LF U of soluble TT. Skin test reactivity was measured as induration $48 \mathrm{~h}$ after test application. Results are given as mean $\pm 1(\mathrm{SD})$. The numbers above the bars represent the number of individuals assayed. 


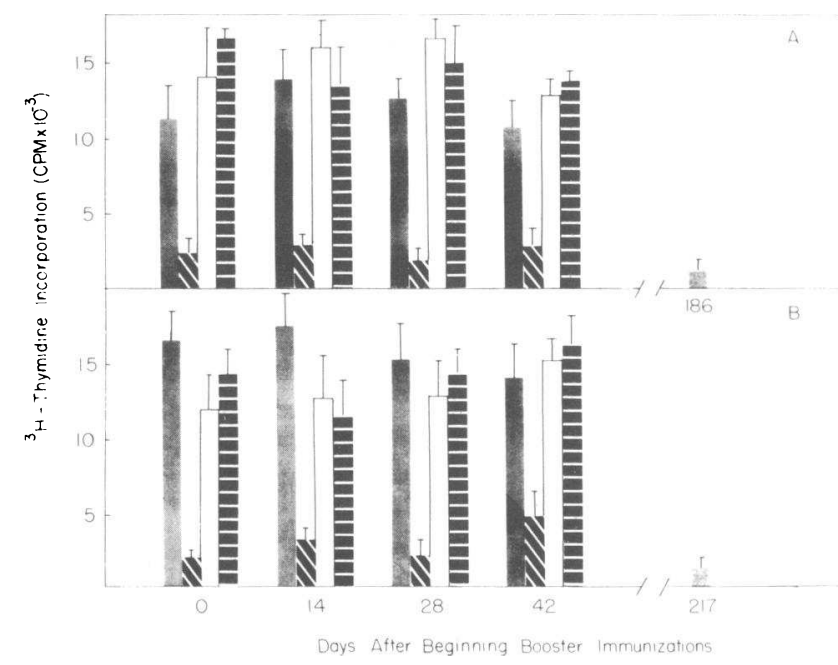

Figure 2. In vitro blastogenesis to TT. Cryopreserved PBM cells $(200,000)$ were incubated with $5 \mu \mathrm{g}$ of soluble TT ( 圈 ) or Candida ( $\square$ ) for $5 \mathrm{~d}$, pulsed with $\left[{ }^{3} \mathrm{H}\right]$ thymidine, and harvested $1 \mathrm{~d}$ later. Immunizations were as in Fig. 1. Cryopreserved cells $(100,000)$ from days $0,14,28$, and 42 were mixed with autochthonous cells from day 186 or 217 as noted and blastogenesis in the cultures determined (shown as striped bars $\mathbb{N}$ for TT and $\Xi$ for Candida). Results are shown as mean \pm 1 (SEM).

than could be accounted for by the addition of the two populations (Fig. 2). These mixes showed no suppression of the response to Candida antigen or PWM.

Effects of serum on in vitro blastogenesis. Autochthonous heat-inactivated serum from days $0,14,28$, and 42 was added to cultures of PBM from day 0. Results are shown in Fig. 3 for $10 \mu \mathrm{l}$ of serum. These cultures showed an inhibition of blastogenesis with sera from days 14-42 without a corresponding fall in responses to Candida or PWM. The sera obtained at day 42 were the most potent. This was not simply owing to the presence of anti-TT as antibody levels were highest early on (day 14) and fell thereafter (Fig. 1). We obtained similar results with $5 \mathrm{ml}$ of sera, though to a lesser degree.

Effects of serum $F(a b)_{2}$ binding fractions. To explore the possibility that anti-anti-TT (anti-id or anti-TT id) was responsible for these observations, $\mathrm{F}(\mathrm{ab})_{2}^{\prime}$ binding material was isolated from the sera of two hyperimmunized donors as described (13). Possible anti-TT antibody was removed from the anti-F(ab)' by passage over a TT affinity column. This anti- $F(a b)_{2}^{\prime}$ material contained undetectable amounts $(<1 \mathrm{ng} / \mathrm{ml})$ of anti-TT antibody activity with direct binding in the solid-phase RIA for IgG antiTT (20). Anti-TT id activity was assayed by using the anti$\mathrm{F}(\mathrm{ab})_{2}^{\prime}$ reagents to competitively inhibit the solid-phase RIA for IgG anti-TT. Briefly, TT was bound to polyvinyl microtitre plates $(\sim 40 \mathrm{ng} / \mathrm{ml})$; varying amounts of anti-F( $(\mathrm{ab})_{2}^{\prime}$ reagents were added along with a known amount (10 ng IgG anti-TT/ well) of a standardized mixed anti-TT antiserum (allogeneic to anti-F(ab)' donors), and the amount of IgG anti-TT bound was measured by binding of affinity-purified, ${ }^{125}$ I-labeled rabbit antihuman IgG. Results obtained with the anti-F(ab) ${ }_{2}^{\prime}$ blocking reagents were compared with control wells. When no anti$\mathrm{F}(\mathrm{ab})_{2}^{\prime}$ antibody was added, the binding of the anti-TT alone gave a mean of $46,382 \mathrm{cpm}$. The anti-F(ab) ${ }_{2}^{\prime}$ alone was the same as background $(1,576)$. If the anti- $\mathrm{F}(\mathrm{ab})_{2}^{\prime}$ fractions had anti-TT id activity, they should block anti-TT binding. Fig. $4 A$ shows the results for the two anti- $\mathrm{F}(\mathrm{ab})_{2}^{\prime}$ reagents. Both sera show a dose-dependent inhibition of the binding of TT to a pool of allogeneic anti-TT IgG antibodies obtained from donors $10 \mathrm{~d}$ after a single booster immunization. To quantitate this inhibition, we performed similar competitive titrations with soluble TT. It took $0.016 \mu \mathrm{g}$ of TT to give $50 \%$ inhibition of binding, $\sim 55$-fold less than with the anti-F(ab) ${ }_{2}^{\prime}(50 \%$ inhibition at 0.99 $\mu \mathrm{g})$. This material did not affect the binding of $\mathrm{IgG}$ antibodies from beekeepers to phospholipase A2 in a similar RIA (21). Anti- $\mathrm{F}(\mathrm{ab})_{2}^{\prime}$ was chosen because normals do not have IgG antiphospholipase $\mathrm{A} 2$ and therefore should not have anti-id activity related to this antigen.

We then tested to see whether the anti-F(ab) ${ }_{2}^{\prime}$ materials would have similar effects in in vitro antigen-driven blastogenesis to the serum from hyperimmunized donors. Various concentrations of these reagents were added at the initiation of antigen(TT and Candida) or PWM-stimulated cultures. Thymidine incorporation was assayed 5-6 d later. These experiments were performed with cryopreserved autologous as well as allogeneic cells because the anti- $\mathrm{F}(\mathrm{ab})_{2}^{\prime}$ inhibited binding of allogeneic antiTT antibodies. These reagents also showed a dose-dependent

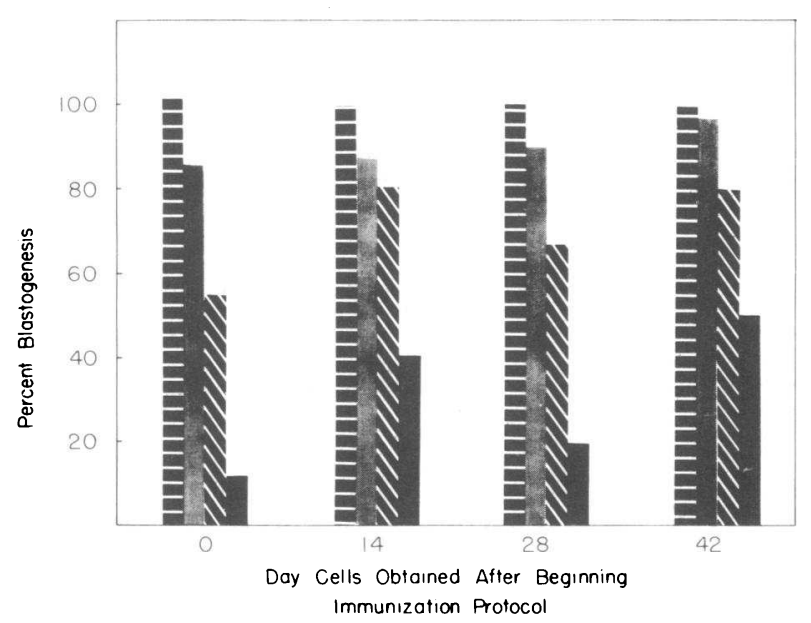

Figure 3. Effect of serum obtained at different times after immunization on blastogenesis by cryopreserved cells taken $0,14,28$, and $42 \mathrm{~d}$ after beginning the booster immunization schedule (see Methods). Each block of four bars shows the level of $\left[{ }^{3} \mathrm{H}\right]$ thymidine incorporation by cells obtained at the day noted in the presence of serum from day 0 ( $\Xi$ ), day 14 ( heat-inactivated serum was added to 200,000 PBM cells in complete medium plus fetal calf serum and $5 \mu \mathrm{g}$ of TT. Cultures were pulsed with $\left[{ }^{3} \mathrm{H}\right]$ thymidine on day 5 and harvested $16 \mathrm{~h}$ later. At each time point for cells, results with day 0 serum $(日)$ were taken as $100 \%$. 

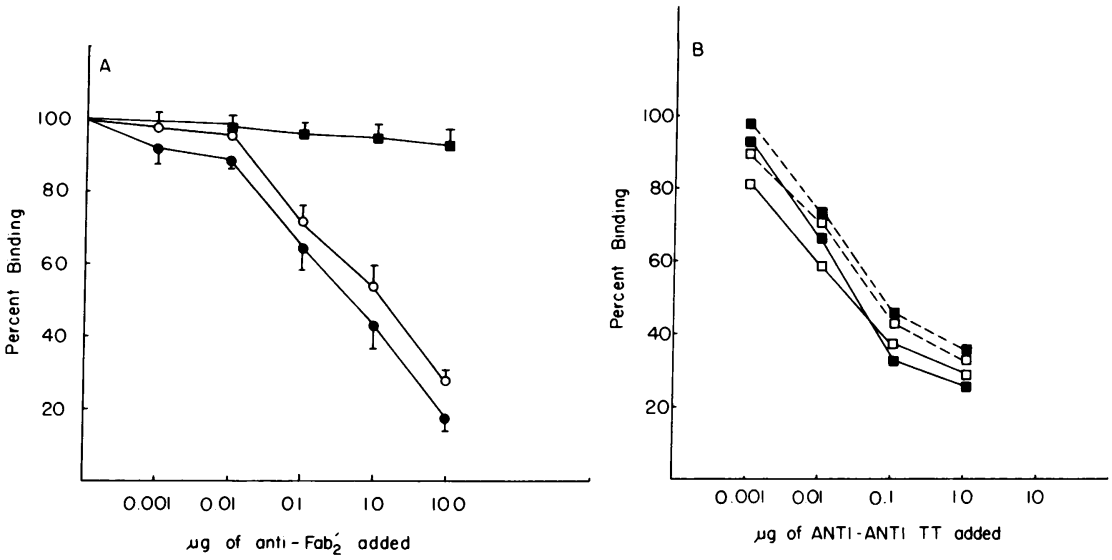

Figure 4. $(A)$ Inhibition of $\operatorname{IgG}$ anti-TT ( $\bullet$ and o) or diphtheria toxin $(\square)$ binding by anti$\mathrm{F}(\mathrm{ab})_{2}^{\prime}$ from two hyperimmunized donors. Increasing amounts of anti- $\mathrm{F}(\mathrm{ab})_{2}$ (nanogram of total protein by optical density) were used to inhibit the binding of allogeneic anti-TT antibodies to TT-coated plates. Points represent mean inhibition for replicate wells \pm 1 (SEM). (B) Inhibition of IgG anti-TT binding to TT by anti-anti-TT antibody from two hyperimmunized subjects ( $\square$ and $\square$ ) different from those in $A$. The dashed lines represent results obtained with the same materials after they had been ultracentrifuged at $10,000 \mathrm{~g}$. ability to inhibit blastogenesis to TT in both autologous and two of three allogeneic donors who had not received a TT booster in $>1$ yr. With one allogeneic normal's cells, the response to TT and Candida were both suppressed. These effects were not attributable to competition for antigen because the reagents had no measurable amount of anti-TT antibody. Furthermore, potential contamination of the anti-F(ab)' with anti-TT would not account for these findings because it took over $5 \mu \mathrm{g}$ of additional TT to so inhibit TT-induced blastogenesis under these conditions.

Effects of specific anti-anti-TT antibodies (anti-TT id). The results with the anti-F(ab) ${ }_{2}^{\prime}$ reagents are clouded by the possible effects of anti-F(ab) ${ }_{2}^{\prime}$ regions unrelated specifically to $T T$. This may have accounted for the lack of specificity seen with cells from one of the allogeneic donors. Therefore, day 46 sera from three individuals were used to prepare anti- $\mathrm{F}(\mathrm{ab})_{2}^{\prime}$ antibodies specific for anti-TT. These were tested for their ability to block TT-anti-TT-binding in our solid-phase RIA as well as for their effect on TT-induced blastogenesis. When these anti-TT id were added to an allogeneic serum pool containing IgG anti-TT antibody from allogeneic donors 2 wk after booster immunization, a dose-dependent inhibition of antibody binding was observed. All three anti-id showed a dose-dependent inhibition of antiTT binding similar to that seen with the anti-F(ab) reagents, except that equivalent levels were blocked by $\sim 50$-fold less total protein $(0.017,0.018$, and $0.020 \mu \mathrm{g})$.

As this inhibition level was striking, similar anti-anti-TT reagents were generated from 42-d sera from two other subjects immunized according to the described protocol. The materials eluted from the anti-TT affinity column demonstrated $50 \%$ inhibition, as above, with 0.023 and $0.031 \mu \mathrm{g}$. However, after ultracentrifugation to remove aggregates formed during preparation, the blocking ability of these preparations was decreased $\sim 2.5$-fold (Fig. $4 \mathrm{~B}$ ). This probably resulted because multivalent aggregates of the anti-id were at a kinetic advantage compared with tetanus or bivalent antibody and/or aggregates could sterically block a bivalent anti-TT antibody binding to the TT plate after binding to only one of its antibody-combining regions.

PBM from the same three allogeneic donors used for assaying
TT blastogenesis with the anti- $\mathrm{F}(\mathrm{ab})_{2}^{\prime}$ reagents were tested in the presence of the specific anti-id reagents for activation by TT, Candida, and PWM. The anti-id showed specific inhibition of transformation to TT. The nonspecific inhibition of Candida in normal donor 3 was not seen (Table I). While maximum inhibition was achieved at lower protein concentrations with the anti-id, the absolute level was not increased when higher amounts of anti-id were added. The suppression of TT-induced blastogenesis by these reagents could not be reversed by addition of up to 10-fold greater (50 ng) quantities of stimulating antigen (TT).

Anti-id reagents activate a third set of antigen-specific $T$ suppressor cells in many elegant murine models of DTH (22).

Table I. Inhibition of TT Blastogenesis by Anti-Id or Anti-F(ab) ${ }_{2}$

\begin{tabular}{lccr}
\hline & \multicolumn{3}{c}{ Inhibition } \\
\cline { 2 - 4 } & TT & Candida & PWM \\
\hline & & $\%$ & \\
Anti-id added (ng/ml) & & & \\
0.1 & 15 & 7 & -4 \\
1.0 & 32 & 5 & 8 \\
10.0 & 60 & 10 & 6 \\
100.0 & 74 & 6 & -7 \\
Anti-F(ab) ${ }_{2}^{\prime}$ added (ng/ml) & & & \\
5.0 & 19 & 22 & 4 \\
50.0 & 36 & 40 & 10 \\
500.0 & 59 & 56 & 14 \\
1000.0 & 82 & 89 & \\
\hline
\end{tabular}

Data shown from the one donor who demonstrated lack of specificity with $F(a b)_{2}^{\prime}$ reagent.

Blastogenesis $\left({ }^{3} \mathrm{H}\right]$ thymidine incorporation) by 200,000 cells with stimulus minus background of cells alone was taken as control. Percent inhibition $=(1-[$ control - experimental $] /$ control $) \times 100$. Mean control stimulation of cells was 12,631 for TT, 10,432 for Candida, and 39,674 for PWM. 
Therefore, we preincubated fresh $\mathrm{T}$ cells with varying concentrations of anti-id material, washed the cells three times in $37^{\circ} \mathrm{C}$ medium, irradiated them $(3,000 \mathrm{rad})$ to prevent blastogenesis, and added them back to autologous $\mathrm{T}$ cells in the presence of TT. Blastogenesis was determined $5 \mathrm{~d}$ later. With preincubation times up to $24 \mathrm{~h}$ no effect was observed, whereas longer incubations showed increasing nonspecific inhibition similar with anti-id incubation and controls (IgG devoid of anti-TT and antiid activity) (results not shown).

\section{Discussion}

Data are available about the role of serum factors, including antibody itself, in the specific and nonspecific regulation of immune responses (23). Recently, much interest has focused on the role of antibody directed to antibody variable region determinants (anti-id) in controlling immune expression (2-4). While these effects were initially focused on B cell responses, it is now clear that id-anti-id interactions are equally relevant to $T$ cell responses $(5-7)$.

While investigating the effect of repetitive in vivo TT challenge on in vitro antibody synthesis, we noted the development of specific in vivo T cell anergy to TT. We analyzed this using antigen-induced blastogenesis, which correlates well with in vivo DTH. The striking finding in the initial experiments was that even with complete in vivo anergy at days $35-36$, blastogenesis to TT was preserved. However, the addition of autochthonous serum from the later times to cryopreserved cells from day 0-43 showed a dramatic inhibition of TT blastogenesis. This effect was not seen with serum from $10 \mathrm{~d}$ post booster immunization, which clearly argues against it being simply an effect of anti-TT because serum antibody levels were as high or higher at day 10 than at day 35 . Furthermore, anti-F(ab)' and anti-TT-F $(\mathrm{ab})_{2}^{\prime}$ fractions from the late phase sera also could inhibit in vitro autochthonous and allogeneic TT blastogenesis. While many cells proliferate in vitro in a nonspecific fashion after specific antigen stimulation, this is dependent on the initial activation of antigen-specific responder cells. Thus the inhibition of the TT specific cells would account for the high percentage of inhibition of total blastogenesis in these cultures (Table I). $\mathrm{T}$ helper/inducer cells have been shown to recognize shared id determinants (24). Our materials were shown to be devoid of anti-TT activity by RIA $(<1 \mathrm{ng} / \mathrm{ml})$. We chose to call the latter material (anti-TT-F $(\mathrm{ab})_{2}^{\prime}$ ) anti-id because these serum fractions were shown to block binding of a pool of allogeneic anti-TT to TT in our solid-phase RIA. Thus, we propose that the initial phase of in vivo T cell anergy to TT seen with repetitive immunization was due to the presence of an anti-TT id activity detected as primarily reactive against $T$ cells. We found no evidence for an effect on expression of $B$ cell function, because serum antibody levels were unaltered by the immunization regimen. However, as we (in collaboration with Dr. Ronald Stevens, Dept. of Microbiology and Immunology, UCLA Medical Center, Los Angeles, CA) have been unsuccessful in analyzing the clonal nature of the B cell repertoire to TT due to its heterogeneity, it is entirely possible that distinct alterations in anti-TT B cell clones occur that give rise to different id, affinities, etc. Furthermore, complementary id interactions may prove to protect clones of id-bearing cells as well as act in an inhibitory fashion (25). The effects we observed were not due to or related to the multiple skin tests alone, as two subjects receiving the same skin tests without the booster immunizations did not develop anergy to TT or suppressive serum. In contrast, three persons given the immunizations alone and then tested on day 42 did manifest these changes.

Anti-id activity has recently been reported in a small number of human models. Geha and Weinberg (13) have examined the effect of xenosera directed to TT antibody in a few normal individuals. While they found a striking effect on $B$ and $T$ cell responses in vitro, these anti-id xenoserum showed individual specificity (26). This is in contrast to our findings where our auto-anti-id reagents reacted with $\mathrm{T}$ cells from other individuals. The likeliest explanation for these discrepancies is that the use of xenosera or solely autologous systems to detect complementary id interactions preferentially selects for private id systems. We attribute our success in detecting broad reacting anti-id material to a combination of factors: our use of serum from hyperimmunized subjects; our observation and subsequent testing of $T$ cell reactivity, as $T$ cells appeared to display a more restricted repertoire of id; and our use of isologous serum rather than strictly autologous or xenogeneic materials for purifying and analyzing in RIA inhibition. In contrast to our findings, Geha detected individual specific id that did not show allogeneic effects; however, his absorption on isologous IgG would remove any public specificities similar to those we describe (27). Furthermore, we used five rather than one booster to develop our anti-anti-id. Use of isologous anti-id materials has been effective in delineating shared id determinants for murine IgG and IgE penicilloyl antibodies (28), and allogeneic responses to dextran favor development of anti-crossreacting id (29). Furthermore, the concept of shared id between humans for antibodies to hepatitis B has now been reported by Kennedy and Dreesman (30).

Many of our experiments strongly suggest that the material we detected in vitro was true auto-anti-id. It was anti-F(ab) ${ }_{2}^{\prime}$, anti-TT $F(a b)_{2}^{\prime}$, and inhibited TT-anti-TT antibody binding. Whether this activity is due to a single or small number of broad crossreacting id present on $\mathrm{T}$ cells specific for TT or the presence of a multiplicity of individual id-anti-id reactions cannot be determined directly from our data. We feel the activity is due to single id, as an accumulating body of evidence suggests the presence of major crossreacting ids between murine species (31-35), while there is little to suggest significant concordance of private id between strains or outbred individuals.

We propose that the auto-anti-id TT observed reacted primarily with id-positive $T$ cells. This would account for the specific loss of in vivo DTH and in vitro blastogenesis. Moorhead et al. $(36,37)$ have described such a model in Balb $\mathrm{C}$ mice where immunization with DNFB leads to an anti-id antibody response 
that tolerizes contact sensitization. Attempting to test whether the antibody response and the possible auto-anti-id we detected in vitro related to the observed loss of TT DTH, we TT-hyperimmunized an individual with acquired hypogammaglobulinemia. Since this individual could not mount an antibody response, we predicted we would fail to tolerize his DTH to TT. This proved to be correct.

Initially we suspected the early participation of antigen-specific $\mathrm{T}$ suppressor cells. However, many experiments mixing autologous cryopreserved cells from day $0-42$ failed to indicate the presence of TT-specific inhibitory cells. Indeed TT blastogenesis was preserved in vitro when the cells were washed and cultured in fetal calf serum or day 0 autologous serum. However, when blastogenesis to TT was tested 6 mo and later in TT anergic subjects, it was markedly depressed compared with day 0 cells. Furthermore, the later cells were shown to suppress TT selectivity. On sequential testing, cutaneous anergy has persisted for over $2 \mathrm{mo}$ in $75 \%$ of those followed and for $2 \frac{1 / 2}{\mathrm{yr}}$ in one individual. Thus, it appears that long-term anergy to TT is associated with the late development of antigen-specific $T$ suppressor cells. This is analogous to findings of Rocklin et al. (38) who demonstrated a specific loss of in vitro $T$ cell reactivity to ragweed antigen after desensitization therapy. The finding of auto-anti-id antibody with the later development of antigenspecific $T$ suppressor cells has parallels to the models of proposed regulation of DTH $(22,39-42)$, where anti-id second set activity (our auto-anti-TT-id) later gives rise to third set antigen-specific $T$ suppressor cells (our late phase antigen-specific cells). Recognizing this, we attempted but failed to induce $\mathrm{T}$ suppressor effector cells by up to $24 \mathrm{~h}$ preincubationn of $\mathrm{T}$ cells with antiTT-id antibodies. This was not too surprising, as such induction in vitro models in murine requires 3-4 d (by which time all the human cells showed activation of nonspecific suppressor cells). Furthermore, in vivo antigen priming or cellular interactions may be required before in vitro induction.

We have been able to define an auto-anti-id antibody system in humans that appears to have the characteristics of a crossreacting or family of crossreacting id. We could relate this activity to $T$ cell responsiveness in vivo and in vitro and to the later development of antigen-specific $\mathrm{T}$ suppressor cells. We are currently trying to develop a repertoire of human anti-TT monoclonal antibodies to determine whether we are truly dealing with a single or family of major crossreacting id.

\section{Acknowledgments}

We wish to thank Ann Fischer and Aimee Nguyen for their excellent technical assistance.

This work was supported by U. S. Public Health Service grants AI15251 and CA-12800.

\section{References}

1. Fauci, A. S., and R. Ballieux. 1982. Human B Lymphocyte Function. Raven Press, New York. 1-336.
2. Hiernaux, J. 1981. Antiidiotypic networks. Fed. Proc. 40:14841488.

3. Binz, H., A. Kimura, and H. Wigzell. 1975. Idiotype positive T-lymphocytes. Scand. J. Immunol. 4:413-420.

4. Infante, A. J., P. D. Infante, S. Gillis, and C. G. Fathman. 1982. Definition of $\mathrm{T}$ cell idiotypes using anti-idiotypic antisera produced by immunization with T cell clones. J. Exp. Med. 155:1100-1107.

5. Cowdery, J. S., and A. D. Steinberg. 1981. Serum antibody-binding antibodies produced during a primary antibody response. J. Immunol. 126:2136-2138.

6. Scott, M. G., and J. B. Fleischman. 1982. Preferential idiotypeisotype associations in antibodies to dinitrophenyl antigens. J. Immunol. 128:2622-2628.

7. Conger, J. D., G. K. Lewis, and J. W. Goodman. 1981. Idiotype profile of an immune response. I. Contrasts in idiotypic dominance between primary and secondary responses and between IgM and IgG plaque-forming cells. J. Exp. Med. 153:1173-1186.

8. Zancili, M., and P. Bigazza. 1981. Anti-idiotypic immunity and autoimmunity. I. In vitro and in vivo effects of anti-idiotypic antibodies to spontaneously occurring autoantibodies to rat thyroglobulin. Eur. J. Immunol. 11:187-195.

9. Bona, C., and J. Kearney. 1981. Anti-immunoglobulin antibodies. II. Expression of individual and cross-reactive idiotypes on syngeneic and homologous anti-idiotype antibodies. J. Immunol. 127:491-495.

10. Klaus, G. G. B. 1978. Antigen-antibody complexes elicit antiidiotypic antibodies to self-idiotypes. Nature (Lond.). 272:265-266.

11. Wullmart, C., J. Wikler, and J. Urbain. 1977. Induction of autoantiidiotypic antibodies and effects on the subsequent immune response. Mol. Immunol. 16:1085-1092.

12. Schrater, F. A., E. A. Goidl, G. T. Thornbecke, and G. W. Siskind. 1979. Production of auto-anti-idiotypic antibody during the normal immune response to TNP-Ficoll. J. Exp. Med. 150:138-153.

13. Geha, R. S., and R. P. Weinberg. 1978. Anti-idiotypic antisera in man. I. Production and immunochemical characterization of antiidiotypic antisera to human antiteranus antibodies. J. Immunol. 121:1518-1523.

14. Abdou, N. I., H. Wall, H. B. Lindsley, J. F. Halsey, and T. Suzuki. 1981. Network theory in autoimmunity. In vitro suppression of serum anti-DNA antibody binding to DNA by anti-idiotypic antibody in systemic lupus erythematosus. J. Clin. Invest. 67:1297-1304.

15. Nasu, H., D. Chia, D. W. Knutson, and E. V. Barnett. 1980. Naturally occurring human antibodies to the $F(a b)_{2}^{\prime}$ portion of IgG. Clin. Exp. Immunol. 42:378-386.

16. Fairshter, R. D., D. B. Thornton, H. R. Gottschalk, L. M. Slater, and M. D. Galant. 1980. In vivo and in vitro cell-mediated immunity to tetanus toxoid in adults. J. Allergy Clin. Immunol. 66:452-457.

17. Saxon, A., J. Feldhaus, and A. Robins. 1976. Single step separation of human T and B cells using AET treated SPBC rosettes. J. Immunol. Methods. 12:285-288.

18. Yamagata, J., E. V. Barnett, C. W. Kriutson, H. Nasu, and D. Chia. 1979. Characterization and measurement of anti-IgG antibodies in human sera by radioimmunoassay (RIA). J. Immunol. Methods. 29:43-56.

19. Nissinoff, A., F. D. Wissler, L. N. Lipman, and D. L. Woernley. 1960. Separation of univalent fragments from the bivalent rabbit antibody molecule by reduction of disulfide bonds. Arch. Biochem. Biophys. 89:230-244.

20. Stevens, R. H., and A. Saxon. 1979. Reduced in vitro production of anti-tetanus toxoid antibody after repeated in vivo immunization with tetanus toxoid. J. Immunol. 122:592-598. 
21. Saxon, A., H. Mawhinney, and R. Stevens. 1982. Alterations in functional human B-cell subsets that produce IgG and IgE. In Human B-Lymphocyte Function, Activation and Immunoregulation. A. Fauci and R. Bellieux, editors. Raven Press, New York. 73-88.

22. Muneo, T., M.S. Sy, B. Whitaker, J. Nepom, R. Finberg, R. N. Germain, A. Nissinoff, B. Benacerraf, and M. I. Greene. 1982. Biologic activity of an idiotype-bearing suppressor $\mathrm{T}$ cell factor produced by a long-term $\mathrm{T}$ cell hybridoma. J. Immunol. 128:49-53.

23. Graf, M. W., and J. W. Uhr. 1969. Regulation of antibody formation by serum antibody. I. Removal of specific antibody by means of immunoabsorption. J. Exp. Med. 130:1175-1186.

24. Gleason, K., and H. Kohler. 1982. Regulatory idiotypes: T helper cells recognize a shared Vh idiotype on phosphorylcholine-specific antibodies. J. Exp. Med. 156:539-549.

25. Rowley, D. A., P. Griffith, and I. Lorbach. 1981. Regulation by complementary idiotypes. J. Exp. Med. 153:1377-1390.

26. Geha, R. S. 1983. Presence of circulating anti-idiotype-bearing cells after booster immunization with tetanus toxoid (TT) and inhibition of anti-TT antibody synthesis by auto-anti-idiotypic antibody. J. Immunol. 130:1634-1639.

27. Geha, R. S. 1982. The presence of auto-anti-idiotypic antibody during the normal human immune response to tetanus toxoid. J. Immunol. 129:139-144.

28. Blaser, K., T. Nakagawa, and A. L. de Weck. 1981. Investigation of a syngeneic murine model for the study of IgE antibody regulation with isologous antiidiotypic antibodies. Int. Arch. Allergy Appl. Immunol. 64:42-50.

29. Schuler, W., E. Weiler, and I. J. Weiler. 1981. Biological and serological comparison of syngeneic and allogeneic anti-idiotypic antibodies. Mol. Immunol. 18:1095-1105.

30. Kennedy, R. C., and G. R. Dreesman. 1983. Common idiotypic determinant associated with human antibodies to hepatitis B surface antigen. J. Immunol. 130:385-389.

31. Hirai, Y., E. Lamoyi, Y. Dohi, and A. Nissinoff. 1981. Regulation of expression of a family of cross-reactive idiotypes. J. Immunol. 126:71-74.

32. Benjamin, C. D., A. Miller, E. E. Sercarz, and M. A. Harvey. 1980. A predominant idiotype on anti-hen egg white lysozyme antibodies from diverse mouse strains. J. Immunol. 125:1017-1025.

33. Shyr-Te, J., M. Pierres, R. Germain, and B. Benacerraf. 1981.
Idiotypic analysis of anti-GAT antibodies. VIII. Comparison of interstrain and allotype-associated idiotypic specificities. J. Immunol. 126:177-182.

34. Sharon, J., L. D'Hoostelaere, M. Potter, E. A. Kabat, and S. L. Morrison. A cross-reactive idiotype, QUPC52 IdX, present on most but not all anti anti (1-6) dextran-specific IgM and IgA hybridoma antibodies with combining sites of different sizes. J. Immunol. 128:498-500.

35. Metzger, D. W., A. Furman, A. Miller, and E. E. Sercarz. 1981. Idiotypic repertoire of anti-hen eggwhite lysozyme antibodies probed with hybridomas. Selection after immunization of an IdX marker common to antibodies of distinct epitope specificity. J. Exp. Med. 154:701712 .

36. Moorhead, J. W., and M. S. Sy. 1982. Antigen receptors on murine $\mathrm{T}$ lymphocytes in contact sensitivity. II. Preparation and characterization of syngeneic anti-idiotype serum against DNFB-sensitized T cells. J. Immunol. 128:2533-2538.

37. Moorhead, J. W. 1981. Antigen receptors on murine T lymphocytes in contact sensitivity. I. Functional inhibition of effector of $T$ cells by monovalent DNP: implications for a two-model. J. Exp. Med. 154:1811-1826.

38. Rocklin, R. E., D. K. Greineder, and K. L. Melmon. 1980. Generation of antigen specific suppressor cells during allergy desensitization. N. Engl. J. Med. 302:1213-1219.

39. Sy, M. S., M. H. Dietz, R. N. Germain, B. Benacerraf, and M. I. Greene. 1980. Antigen- and receptor-driven regulatory mechanisms. IV. Idiotype-bearing I-J+ suppressor T cell factors induce second-order suppressor T cells which express anti-idiotype receptors. J. Exp. Med. 151:1183-1195.

40. Sy, M. S., A. Nissinoff, R. N. Germain, B. Benacerraf, and M. I. Greene. 1981. Antigen- and receptor-driven regulatory mechanisms. VIII. Suppression of idiotype negative ABA specific $T$ cells results from the interaction of an anti-idiotype Ts 2 with a CRI+ primed T cell target. J. Exp. Med. 153:1415-1425.

41. Okuda, K., M. Mutsuhiko, S. Furusawa, and M. E. Dorf. 1981. Analysis of $\mathrm{T}$ cell hybridomas. II. Comparisons among three distinct types of monoclonal suppressor factors. J. Exp. Med. 154:1838-1851.

42. Sherr, D. H., and M. E. Dorf. 1981. Hapten-specific T cell responses to 4-hydroxy-3-nitrophenyl acetyl. IX. Characterization of idiotype-specific effector-phase suppressor cells on plaque-forming cell responses in vitro. J. Exp. Med. 153:811-822. 